\title{
Epilogue: Infertility and the Study of Women's History
}

To study barrenness is to study the history of women's struggles in a distilled form. Infertile women encountered the same expectations, were subject to the same restrictions, looked to the same forms of support, and engaged in the same religious practices as did fertile women; but the constraints and opportunities that accompanied womanhood had repercussions that were potentially more weighty for them. By studying the factors which particularly informed the lives of barren women, we also illuminate important swaths of women's experiences more generally. The purpose of this book, therefore, has been to establish a framework for inquiry into medieval barren women's experiences, one that can help orient us as we try to identify what was at stake for these women, what possibilities were available to them, and how women invested their energies.

This book has examined three bodies of evidence which can inform us about the experience of female infertility: Islamic legal discussions pertaining to women's reproductive capacities, Arabo-Galenic medical texts, and religious works preaching about medical practitioners and healing practices. These three foci reflect the aspects of women's infertility which had the most to do with men and, more specifically, the aspects of women's infertility which were most subject to the influence exerted by exclusively male institutions. The choice to attempt to understand women's experiences through such masculine lenses might have initially struck readers of this study as odd, even frustrating. This methodology, however, has its strengths.

Among my primary reasons for studying women's history in this way is my desire to answer questions that are important to my own $21^{\text {st }}$-century community without mischaracterizing what was important to the older communities I study. I have attempted to produce an analysis which speaks to issues of patriarchy, the construction of gender, feminine ritual, and women's empowerment, and to shed light on these concerns in a way which respects and preserves the modes of thought, the genre expectations, and the authorial intent behind these medieval texts. Of all the sources we have available, the books produced by the jurists and the physicians are best-suited to this task because these genres are better understood by historians than are other written sources (for the moment at least), and because they exist in great abundance and have attracted a great deal of scholarly attention. My hope is that by rooting my exploration in these texts, the medieval people who are at the center of this endeavor would recognize the individual topics of discussion in this book as familiar ones, though they might be

Ә OpenAccess. ( 2020 Sara Verskin, published by De Gruyter. (cc) BY-NC-ND This work is licensed under the Creative Commons Attribution-NonCommercial-NoDerivatives 4.0 License. 
surprised by the juxtaposition of those individual topics or the weight attributed to them.

This study deals in generalizations and possibilities. I hope some students of women's history will find the generalizations useful for alerting them to phenomena they would have otherwise failed to notice and for helping them to make sense of their own explorations into the lives of individuals and individual communities. I hope still others will come forward with counter-examples to my arguments, and with modifications and improvements upon my theories. The study of women's social history in the medieval Middle East is still at its early stages, and we have a great deal of work to do to begin to do justice to the experiences of those women.

\section{Infertility and family law}

Certain underappreciated aspects of marital law and social practice had a disparate impact on barren women. For example, we have seen that first marriages for medieval women frequently took place at an age when women were likely to have been developmentally sub-fecund. This has consequences for understanding infertility, but it also has consequences for understanding women's history more broadly. With regard to infertility, the implications of early marriages are, first, that women may well have come to be viewed as infertile much earlier in their lifetimes than they would today, and consequently would have experienced the pressure to find a cure early on. Such cures could themselves exacerbate fertility problems or create ones where none existed. A second implication of early marriage is that, in the worst circumstances, coitus could itself result in damage to a girl's reproductive organs. Such situations are mentioned in Islamic legal manuals and some fatwā collections, though I surmise that they were rare. However, even when early marriage did not have these severe medical consequences, the phenomenon may inform our understanding of certain marriage dynamics. If many women did not complete the puberty process until they were in their early 20s, then wives in their mid-teens likely appeared to be physically more child-like than they do today, and thus more likely to be viewed as in need of protection, tutelage, and supervision. It is perhaps then no wonder that, for first marriages, brides were given little autonomy, ${ }^{744}$ and their preferences commanded relatively little respect; but, when they became matrons, moth-

744 See K. Ali, Marriage and Slavery in Islam, 33. 
ers-in-law, widows, or divorcées, they seem to have acquired much more authority. $^{745}$

With regard to Islamic law, infertility highlights medieval ambivalence toward the institutions of divorce and polygamy. In some instances, divorce seems to have been viewed as running counter to the barren wife's interests, and this made the option of accepting polygamy as a means of avoiding divorce sometimes palatable. Sometimes infertile women who were subject to the threat of divorce would attempt to shield themselves from its effects by insisting that they were in fact pregnant, or had not menstruated, and thus they could continue to be attached to their former husband for an extended period of time. On the other hand, we also hear of women attempting to hasten divorce proceedings so that they could find new husbands, and sometimes having trouble doing so because they were not menstruating regularly.

While menstrual irregularity and unusual claims of pregnancy had special implications for infertile women, they also have much to teach us about women's experiences more broadly. Uncertainty surrounding menstruation and conception highlights the extent in which women had some degree of privacy and ability to choose how to present their bodies. We have seen that, in biological matters which were legally significant for marriage and divorce, women in a range of societies seem to have been in a position to conceal, reveal, or define their own status before society at large and before their husbands. We have encountered newlywed husbands who seem to be surprised to find that their wives are younger than expected or are not menstruating regularly. We have seen husbands and wives resorting to the competing testimonies of midwives to establish the wife's level of maturation or pregnancy status. We have seen wives and midwives expediently changing their testimony about pregnancy status. Women themselves testify about whether or not they have menstruated or felt signs of pregnancy. They even testify as to whether the father of their fetus is a long dead husband rather than a living one. This has implications for our understanding of how women managed the intrusion of society at large into intimate matters that were considered to be of public religious and legal concern, such as the preservation of clear-cut lines of paternity. The dependence upon women's testimony suggests that, despite the scrutiny and restrictions attached to women's reproductive roles, in many communities women did have opportunities for privacy. This

745 Cf. Goitein, Mediterranean Society, 3:162-4. For an illuminating anthropological discussion of how assessments of a woman's competence change over the course of her lifetime within a rural Egyptian village see Morsey, Gender, Sickness, and Healing in Rural Egypt: Ethnography in Historical Context, 52-4. 
means that women could sometimes not only fashion their own responses to external pressures on them, but could also exert a practical pressure of their own. We see this, for example, with the woman who claimed to be carrying her long dead husband's child, even when she remarried. ${ }^{746}$ Due to her testimony, her deceased husband's relatives consider her child to be one of their own kin. In this way, women were sometimes invested with a certain trust and a capacity for defining their own public status.

The study of childlessness also highlights conflicting attitudes towards women's inheritance rights and, more fundamentally, toward their familial affiliation. A married woman was part of two families, the one she was born into and the one she married into, and she transferred wealth between them. ${ }^{747}$ She received wealth from her birth family via her dowry and through her inheritance. If she had children at the time of her death and she predeceased her other heirs, her father and her mother would inherit one sixth each, and the rest would be inherited by her husband and children. Thus, two thirds would be lost to the birth family. If she had no children, her birth family would lose half, and that would include half of her trousseau, items which had sentimental as well as monetary value, and which would pass into the hands of the husband and his family. If, on the other hand, a woman was predeceased by her husband, then she would inherit from him an eighth of his wealth if he had a child, and a quarter of his wealth if they were childless, thereby depriving the other heirs from his family of it. In theory, such laws meant that married women always represented the removal of a significant amount of wealth from one of their two families, but childless married women represented an often greater loss with fewer tangible benefits. We see that when married childless women predeceased their husbands, the women's birth families pursued aggressive legal measures to prevent such losses. Meanwhile, childless widows were at risk of being disinherited in favor of their husbands' blood relatives. ${ }^{748}$

746 al-Wansharīsī, al-Mi'yār al-Mu'rib, 4:54-5.

747 By contrast, her husband belonged to the family in which he was born, and their son would be part of his father's family too. This form of association is visible in a variety of settings, but it is most easily seen in the Islamic inheritance laws pertaining to grandchildren. The son of a son belonged to his father's and paternal grandfather's lineage, and he could potentially inherit from his paternal grandfather and paternal uncles. But the son of a daughter did not belong to his maternal grandfather's lineage, and could not inherit from any of his maternal relatives other than from his mother herself.

748 E.g. The story of Khātūn and Dalīla in Alif Layla or Book of the Thousand Nights and One Night, W. H. Macnaghten (Calcutta, 1839), 3:418. 


\section{Medieval gynecology and its significance}

Medieval Arabo-Galenic gynecology highlights the complicated relationship between scientific and religious understandings of anatomy and reproduction. Some of the theories put forth in medical books matched religious beliefs and correlated with legal and practical norms. For example, as Basim Musallam has shown, the two-seed understanding of conception was a scientific theory particularly favored by Ibn Sīnā and his physician-jurist successors such as Ibn Qayyim al-Jawziyya. It also matched up with a particular hadith ascribed to the Prophet Muhammad, and correlated with a legal and practical willingness to make use of contraception. ${ }^{749}$ Similarly, the notion that breastmilk was made from menstrual blood accorded well with Islamic notions of kinship via breastmilk. This concept was retained even as a competing notion that milk was a product of semen was also widely believed. ${ }^{750}$

Not all biological ideas that had religious importance were echoed in AraboGalenic gynecological literature, however. And not all gynecological knowledge had an impact on religious thought. The concept of the "sleeping fetus" was not integrated into Arabo-Galenic gynecology. Nor, for that matter, was religious interest in virginity. In the opposite direction, scientific tests of fertility were never integrated into Islamic legal thought.

Similarly, medical theorization about gender differences did not necessarily mirror social attitudes towards gender relations. Sherry Sayed Gadelrab, for example, published a substantial article on medical depictions of the anatomical differences between the genders. ${ }^{751}$ Gadelrab's article takes up the question of whether the physicians of the medieval Islamic world viewed women's anatomies and hence qualities as essentially defective versions of men's bodies and qualities, or whether (to borrow a slightly more modern turn of phrase, which is not Gadelrab's) "men are from Mars and women are from Venus," i.e. two opposite species. ${ }^{752}$ When analyzing Ibn Sīnā's work, she noted that in his Qānūn, a work focused on medical treatment, he depicts male and female genitalia as

749 A. Giladi, Infants, Parents and Wet Nurses: Medieval Islamic Views on Breastfeeding and Their Social Implications, 60.

750 Ibid. 21, 26, 80.

751 S. Gadelrab, "Discourses on Sex Differences in Medieval Scholarly Islamic Thought," Journal of the History of Medicine and Allied Sciences 66 (2011), 40-81. Cf. A. Ragab, "One, Two, or Many Sexes: Sex Differentiation in Medieval Islamicate Medical Thought” Journal of the History of Sexuality, 24(2015), 428-454.

752 The question relates to the thesis articulated in Thomas Laqueur's Making Sex: Body and Gender from the Greeks to Freud (Cambridge: Harvard University Press, 1990). 
near equivalents, which were to be treated based on shared premises about bodily health, from the point of view of the physician. However, in his book on nature, the Kitāb al-ḥayawān, Ibn Sīnā depicted masculine and feminine nature as "more divergent behaviorally in human beings than in any other animal, as has been noticed by the natural philosophers." 753 Thus, Ibn Sīnā could hold the view that men and women are completely different and unequal (with women comparing unfavorably to men) and could identify that inequality as rooted in anatomy and physiology, while simultaneously arguing that, anatomically, men's and women's reproductive organs were largely equivalents. In other words, even among people who held "chauvinistic" views of women, that chauvinism did not extend into every scientific area involving gender, and even among people who held egalitarian views regarding men and women's reproductive organs, that did not translate into a social egalitarianism.

\section{The quest for conception: women's access to medical practitioners}

In a reassessment of Ullmann's claim that there were no opportunities for theoretically trained physicians to apply their gynecological knowledge due to gender segregation, this book has argued that the preponderance of the evidence available to us suggests otherwise. Medical works, hisba manuals, literary anecdotes, and anti-bid' $a$ literature all indicate that trained male practitioners did treat women in a variety of medical situations, including intimate ones which involved direct observation of the patient, taking her pulse, bleeding and cupping her, discussing contraceptives and abortifacients, and operating in the area of the groin. There is little reason to doubt that such interactions were commonplace in many parts of the Middle East. As for the propriety of medical situations which involved viewing and touching women's genitals and performing surgery on them, the textual evidence is more varied. Such interactions are described in medical manuals, sometimes with a midwife taking on an explicitly-defined role as intermediary and sometimes not. Midwives seem to be particularly likely to be mentioned in situations which involved the practitioner introducing a hand or finger into the vagina. However, multiple sources suggest it was thought appropriate for men to engage in clitorectomies, ${ }^{754}$ even though in modern contexts the

753 Gadelrab, 26. citing Ibn Sīnā, Kitāb al-ḥayawān.

754 Al-Zahrāwī, Albucasis on Surgery and Instruments, 457 and Ibn al-Ukhuwwa, The Ma'ālim al-qurba fī aḥkām al-ḥisba, 56. 
practice is largely associated with female practitioners. ${ }^{755}$ Men are also described as working collegially with women practitioners in heroic interventions for obstructed labor and childbirth. Some of the procedures described, however, were likely theoretical possibilities only, rather than practical ones. This is certainly the case with regard to cesarean sections, and probably with regard to perinatal dismemberment, but in other cases the practicability of suggested treatments which involve men in the birthing room is more ambiguous.

Legal and moralistic writings authored by jurists provide a different perspective, one which complements the view we get from medical writings. Their policing of boundaries highlights the prevalence of the opposite phenomenon.

If someone were to say: "But the 'ulamā' have permitted uncovering nakedness before a physician whether the patient is a man or a woman!" the response is that this is the case when there is a necessity, and there is no necessity that calls for inviting an infidel when there exists a Muslim physician. ${ }^{756}$

In this passage, it is clear that in $8^{\text {th }} / 14^{\text {th }}$-century Cairo there is an expectation that the male physician, regardless of religious affiliation, would view and touch his female patient in the course of providing medical attention. It is also clear that there are those in Ibn al-Hājj's audience who commonly assert that jurists have no objection to uncovering nakedness (though Ibn al-Ḥājj does not mentioned whether this includes genitals) before a medical practitioner regardless of gender or religion.

Against this backdrop, Ibn al-Hājj argues that Muslim women should not be revealing themselves even to non-Muslim women, let alone to non-Muslim men. In response to those who raise the argument that the impropriety associated with nakedness does not pertain to medical situations, he argues that the impropriety is still there if a woman is exposed to a non-Muslim, male or female, when she has the opportunity to be seen by a Muslim practitioner. As we have seen, Ibn alHaājj's legal positions on this matter are not unique to him. There was a long tradition, stemming from certain hadiths attributed to the time of 'Umar's conquest of Jerusalem, of forbidding Muslim women from exposing themselves to nonMuslim women. When it came to the practical ranking of preferred medical practitioners, there is a debate among the jurists as to the relative distastefulness of exposing Muslim women to female non-Muslim medical practitioners as opposed to male Muslim ones.

755 Berkey, "Circumcision Circumscribed: Female Excision and Cultural Accommodation in the Medieval Near East," 20.

756 Ibn al-Hāajj, al-Madkhal, 3/4:318. 
The objection to non-Muslim practitioners was not based exclusively on concerns of sexual impropriety. (The concerns extended to male non-Muslim practitioners and their male patients, and even to nominally Muslim practitioners who were overly worshipful of the Greek medical tradition and dismissive of the Prophetic pronouncements on medicine.) Rather, in addition to the issue of sexual exposure, the objections were also based on concerns about the intellectual and spiritual influence healers have over their patients. This is not to suggest that there is a concerted trend in fiqh itself to legislate restrictions on seeking treatment from those practicing Arabo-Galenic medicine. There is no such legal tradition. But there is a history of such sentiments being expressed in the adab literature produced by jurists, who seem to be casting themselves in the role of embattled scolds.

The objections to subjecting oneself to the intellectual and spiritual influence of those who offer a system of belief and a system of authoritativeness outside of the orthodox Islamic one, had particular implications for women. These implications are most clearly articulated by Ibn al-Hāij, but Ibn al-Hājj is certainly operating within a long-standing strand of religious discourse. Ibn al-Hāijj argues not only that non-Muslim women pose an intellectual threat to Muslim women and lead them astray (and through them also their husbands and families) by encouraging the adoption of syncretistic practices, but also that Muslim women can pose this threat as well. This is not entirely the fault of Muslim women or a result of their inborn spiritual deficiencies. Rather, Ibn al-Hājj argues, because Muslim women are secluded from most Muslim men, they do not have sufficient access to the teachers of orthodox Islam (what he refers to as "the pure Law") who are themselves men. The result, he claims, is that there is a religious vacuum among women, a vacuum which creates a space for women to construct and perpetuate their own religious ritual. This ritual centers upon the life cycles and matters of menstruation, sex, birth, sickness, and death.

\section{Infertility and choice}

The legal, biological, scientific, and religious concepts described in this book constitute gravitational poles which exerted sometimes overt and sometimes subtle pressure on the environments in which infertile women found themselves. These forces did not all exert pressure in the same direction. For example, the legal tendency to define the requisites of marriage as based on sexual rights and responsibilities ran afoul of those social pressures which accorded a greater role to the reproductive element of marriage. The desirability of marrying fertile women 
competed with the desirability of marrying virgins, some of whom were too young to be able to show signs of fertility. In the wake of widowhood or divorce, the pressures to ensure lineage by monitoring women's menstrual cycles were hampered by the biological fact that menstrual cycles are inexact proxies for reproductive status. Moreover, the tendency to seclude women from men, and women from society at large during the idda period, made monitoring menstrual cycles difficult or unfeasible. The pressure exerted by Islamic law to include women as heirs to family property competed with the roles women necessarily played as liaisons to other families. The tendency to concentrate both scientific knowledge and religious authority in the hands of men, and to thereby make women dependent on men for medical and religious guidance, ran up against modesty restrictions, restrictions which pulled women towards turning to other women for medical and religious guidance, much to the chagrin of male authorities.

All this means that there was a range of ways in which a barren woman could experience infertility, and there was a range of ways in which people could choose to treat barren women, in both the medical and social senses of "treat." However, many of those choices would have been fraught and unstable. A couple or a husband could choose to remain childless and monogamous, but in such a situation the inheritance system would create conflicts between the couple and their in-laws, and possibly with their own birth families. A woman could choose to seek treatment for her barrenness at the hands of either Galenic medical practitioners, or practitioners of folk medicine, or of magic, or through the intercessions of holy persons - but none of those options would necessarily come without condemnation on the grounds of either sexual impropriety or heterodoxy. This range of choices, and the instability of those choices, takes on greater dramatic significance when we consider that infertility was often a lifelong condition, the ramifications of which changed as husbands and wives progressed into middle and old age. Those choices once made could be revisited again and again over the course of many years. Thus, the experience of infertility was a dynamic one, subject both to forces beyond anyone's control and subject to the individual choices and maneuverings of women, their husbands, their medical practitioners, and their extended families. 